\title{
'Is this a Time of Beautiful Chaos?': Reflecting on International Feminist Legal Methods
}

\author{
Faye Bird ${ }^{1}$
}

Published online: 2 September 2020

(c) The Author(s) 2020

\begin{abstract}
This article considers how Margaret Jane Radin's theory of the feminist double bind can bring conceptual clarity to the difficulties feminisms face in engaging with political and legal institutions of global governance. I draw on her theory to reinitiate a conversation on ideal and nonideal theory, in order to answer the call of key proponents in international legal feminism to reevaluate methodologies in critiquing mainstream institutions. By providing an account of how to navigate the double bind, this article brings conceptual clarity to the tension between resistance and compliance that has been argued to lie at the heart of the feminist project in international law. I demonstrate how this theoretical framework can foster greater pluralist perspectives in feminist engagement of ideal theories to temper the deradicalising and conservative risk of navigating feasibility constrained nonideal strategies.
\end{abstract}

Keywords Feminist methodology · International law · Resistance and compliance · Double bind · Ideal and nonideal theory · UN Security Council · Women, Peace and Security

\section{Introduction}

23 May 2008 Onati to the Future

Is this a time when injury, suffering, indignity, symbolic, material violence, injustice, hunger, poverty are terms that conjure up times gone by? Is this a time of beautiful chaos?

Anonymous postcard to the Future (anonymous in Kouvo and Pearson [2011] 2014, 218)

The above quote forms one of many feminist 'postcards to the future' written by participants of an academic workshop on feminist perspectives in the era of anxiety and

Faye Bird

faye.bird@pgr.reading.ac.uk

1 School of Law, University of Reading, Whiteknights Rd, Early, Reading RG6 7BY, UK 
terror, which took place in Oñati, Spain in 2008. Not only does it convey the hope of the author for a beautiful future, but it invites next generation feminists to ask themselves whether they are living in "a time of beautiful chaos?" (Kouvo and Pearson [2011] 2014, 218).

It is timely to consider this question given prominent calls for a return to methodology. Feminist Legal Studies, in particular, saw the successive publications of Dianne Otto and Anna Grear's conversational article on international law, social change and resistance (2018), and Hilary Charlesworth, Gina Heathcote and Emily Jones' inter-generational discussion concerning feminist scholarship on international law (2019). Both call for a methodological turn within international legal feminism, with the latter positing that now "seems the right time to return to theories and methodologies" (Charlesworth et al. 2019, 4). These are, to a degree, reflections that at once look back and take stock, and look forward speaking optimistically to future feminists. Time is, of course, an important aspect of how we should understand feminist strategies of critical engagement and activism; it anchors feminist agreements and disagreements in a history of struggle and hope.

In responding to the call for methodological thinking, I will consider a fundamental problem international legal feminists face: a tension between engaging with international legal institutions and academic 'mainstreams', which exclude and devalue feminist contributions, on the one hand; or disengaging to pursue critique from the margins, on the other hand. I introduce, as a methodological intervention, a key contribution from Margaret Jane Radin's writing on legal methodology, namely her theory of the feminist double bind (1990, 1699). Her compelling account of the bind captures the tension between nonideal strategies and ideal visions which loom large in feminist thought and activism. Despite thirty years since publication, I provide a novel application of Radin's double bind to feminist epistemologies in international law. I show how it can be traced within patterns of international legal feminist argumentation, thereby situating these particular debates within wider feminist conversations. The bind, I argue, offers evaluative theoretical tools and explicit temporality in navigating this tension. Finally, I depart from Radin to centre ideal thinking in my argument; I turn to conceptual debates within political philosophy to foreground this. In revealing the illuminative, instructive and radical potential of the theory of the double bind, a new analytic lens is offered to the feminist project on international law, as are tools for determining one's own pathway through the project's most foundational tension.

For the purposes of clarity, I will briefly outline what I mean by the feminist double bind. Radin's theory of the double bind reveals that the implicit tension between resistance and compliance is the result of the non-ideal structures and institutions which demand compromising on feminist utopian ideals, leading to hegemonic forms of complicit feminisms at the expense of 'Other' feminisms and social justice projects. Radin observes that a double bind emerges when, in light of a particular feminist ethical question, two general routes emerge for addressing it. Engaging or disengaging, for example, are clear binary options which present themselves for feminists working on, or within, the mainstream. However, there are costs embedded within both of these strategies. Engagement has the potential to give rise to complicity in the cooption of feminist ideas, or exclusion of much of the varied work that 
constitutes the broad church of feminism. Yet disengagement runs the risk of losing 'progress' previously gained, and perpetuating feminisms' exclusion from mainstream institutional action and academic thinking. Radin's theory compels feminists to be explicit when weighing up non-ideal options, before making a temporary decision upon which to take. This decision is recognised as contingent, and continually open to reappraisal. Crucially, this is a self-reflective process, which begs for explicit engagement with the risks and shortcomings of feminist argumentation. This is how one might navigate nonideal options arising from nonideal circumstances. But under the theory of the double bind, feminists should also develop and advance ideal theory, to foster the critical and revolutionary imaginings of feminisms. Exercising ideals protects feminists from operating solely in the realm of the nonideal, where revolutionary visions become hostage to feasibility constraints. It embodies the type of beautiful chaos which departs from the existing status quo of disadvantage and violence, to oscillate between nonideal structures and ideal feminist utopian thinking.

To construct more thoroughly the ideas outlined above, I will follow four stages of argumentation. First, I will provide a brief exegesis of the current terrain of feminist perspectives on international law. I will then introduce Radin's theory of the double bind and show how it can be both a useful heuristic for framing and understanding this key tension, as well as a road map for navigating it. The third stage of the paper uses the United Nations Security Council as a case study for applying the double bind. Given the increasing, hegemonic militarism of the Council, in tandem with its Women, Peace and Security Agenda, it throws into relief this tension for feminisms. The final stage of the paper turns to consider some foreseeable objections a reader may pose to the arguments herein. I consider two potential objections I take to be most pressing: first, the paradox of addressing a binary tension through a dichotomous theoretical framework; and second, that the pragmatism of Radin's double bind fosters a conservative approach to pursuing change. Radin goes some way in guarding against such objections, but I advance the defence by recentring ideal theory as an evaluative process. In so doing, I foreground more seriously the need to practise ideal theory through feminist plurality and radical thinking.

\section{Feminist Pasts; Feminist Futures}

I cannot do justice here to the rich multiplicity of feminist perspectives on international law, which include postcolonial, critical race, queer, poststructuralist, intersectional, and crip encounters with feminism. I will, however, provide a brief exegesis of some key moves within the literature to contextualise the tension between resistance to, and compliance with, institutional and academic mainstreams (Kouvo and Pearson [2011] 2014). I will first outline the emergent methodological turn which motivates this paper, before offering an account of the diversity of feminist theories, and the revolutionary potential of their demands.

Since Hilary Charlesworth, Christine Chinkin and Shelley Wright's groundbreaking article in the American Journal of International Law (1991) feminist insights on international law have flourished, with 2018 marking, what I see as, the beginning of a methodological turn. Feminism(s) as analytical tools became 
the focus of a number of important publications (see Harris Rimmer and Ogg 2019; Heathcote 2019; Hodson and Lavers 2019; Kapur 2018), whilst other key proponents of the field more explicitly called for a renewed interest in feminist epistemologies. Dianne Otto and Anna Grear frame their appeal within a political landscape marred by crisis discourses, the impervious nature of neoliberal capitalism and the continuation of colonial relations (2018, 351-353). Hilary Charlesworth, Gina Heathcote and Emily Jones consider the shifting ground of the international order and its fragmenting legal framework, observing how feminist scholarship has adapted to it (Jones 2019, 1). Both conversations invite a recentring of feminist methodologies in international law, particularly in light of the inroads feminists have ostensibly made into the elite realm of international law and governance. Charlesworth, Heathcote and Jones note that:

Given the preliminary forays gender perspectives have made into the international institutions, it seems the right time to return to theories and methodologies, to ask ourselves what the tools are that feminist approaches bring to international law, what are the tensions and what are the possibilities for feminist approaches to international law, beyond highlighting harm and discrimination against women. $(2019,4)$

Similarly, Otto and Grear stress the need to "work out how to revive the crucial elements of imagined feminist futures" (2018, 353).

Strikingly, both articles draw on the ongoing, historical struggle feminists have had in engaging with the academic and institutional mainstream structures of international law. Charlesworth et al. discuss the concept of the mainstream in two ways. First, in terms of accessing academic and legal institutions, which, they argue, are structurally unaccommodating of the unfair distribution of caring responsibilities women carry $(2019,13)$. This structural critique is buttressed by their normative, second point: the perceived irrelevancy of feminist analyses to the dominant work occurring within the mainstream. They note "feminists in international law are seen, by many, as scholars who work on sexual violence and representation alone" $(2019,8)$, thus their work is considered of little value outside of this silo.

Whilst Charlesworth et al. situate much of their critique and recommendations in past and present practice, Otto and Grear reveal how their respective visions of ideal feminist futures exist at odds with mainstream structures. In rescuing the emancipatory and revolutionary goals of feminist thinking and imagining, they challenge the need feminists may feel to concede too much power in the law. However, this does not amount to turning away from the mainstream: "a feminist logic of social justice and peace needs to operate both outside and within the boundaries of international legal institutions, universities and other institutional fora" $(2018,361)$. The question of how to navigate this tension has been a persistent thorn in the side of feminists working in international law. Kouvo and Pearson have observed that the tension arises between resistance and compliance, which, they argue "is...built into the heart of the feminist project within international law" (Kouvo and Pearson [2011] $2014,5)$. Thus, the identity of the feminist working in, or on, international law is an uncertain one, and one which requires continual reconsidering and renegotiating. 
Critiques of feminist complicity with the mainstream's cooption of some feminist ideas, notably those most amenable to it, observe the exclusion of feminism's more revolutionary demands, as well as feminist 'Others'. In addressing mainstream cooption, reworking and advancing various feminist methodologies is key to ensuring that engagement with feminism is substantiated with feminist meaning. Charlesworth distinguishes between the rhetorical success of feminist messages in institutions and the more revolutionary potential of feminist methods in international law ([2011] 2014, 32). This distinction helps us to see the different depths of feminist analysis: the feminist messages are taken up at a surface level, but are susceptible to cooption and partial realisation whereas feminist methodologies are not taken up, but offer a deeper analysis and critique. Charlesworth argues that "feminist methodologies suggest that prescriptions of women's equality must respond to the needs and desires of women we think we are helping" (Charlesworth [2011] 2014, 32). Thus, the task of reconsidering methods requires a serious engagement with the needs of those who feminism purports to advocate for. However, this raises a potentially problematic power imbalance between feminisms and those who feminists claim to advocate for, or as Janet Halley puts it, "carry a brief for" ([2006] 2008a, 5). As bell hooks makes clear, a feminism which assimilates with the mainstream may do so at the cost of other feminisms $(1984,3)$. It does so, she argues, by claiming to be the feminism for all women; a "hegemonic" version of feminism blind to the different lived experiences, suffering and strength of other feminisms (hooks 1984, 2).

The differences amongst and between feminist strands of thought and their demands are most strained when it comes to the encounters between feminism and the mainstream. As the former seeks to effect change on the latter, feminisms' diversity calls into question who is in the room, the price paid to be there, and who is left outside. Halley's coining of 'governance feminism' (Halley et al. 2006, 2018, 2019) seeks to capture this by conveying the political influence of a particular type of feminism within institutions of power, often at the expense of 'Other' feminisms (what Halley calls "divergent feminisms" ([2006] 2008a, 187)) which demand more than a monolithic, universalist feminist agenda. This throws into sharp relief the issue of feminism as an exercise of representation; both in the sense of political representation (speaking on behalf of $\mathrm{X}$ ), and in the sense of depicting what that group is (Halley [2006] 2008a, 92). In terms of who is represented, Kimberlé Crenshaw has argued that "ignoring difference within groups contributes to tension among groups" (1991, 1242), stemming from the delineating effect of a feminism blind to intersectional disadvantage. A black woman's particular experience, for example, is often lost within social justice responses to either racism, or to sexism, which operate to frame them as exclusive categories (ibid). In a postcolonial feminist context, when Gayatri Chakravorty Spivak asked whether the subaltern could speak (1988), she revealed the complex way in which colonialism, race and gender weaved together particular manifestations of oppression. Spivak argued that the subaltern could not speak the language of the dominant mainstream, thus when feminism 'speaks' the language of the mainstream, it is unlikely to speak the language of subalternity. This is particularly pertinent given the critiques of (neoliberal) international law as an exercise in neocolonialism in its continuation of colonial relations (Kapur 2018, 19; Otto and Grear 2018, 351-353). 
What this brief account of some of the moves within feminism, broadly defined, reveals is that when the mainstream begins to consume (some) feminist ideas within it, the tension between resistance and compliance is heightened. In exchange for even marginal influence, feminism risks being 'watered down' and compromised, both in terms of the revolutionary spirit of its demands, and in terms of who it represents. Value, therefore, lies in the collective tolerance of the various priorities of feminisms. As Otto and Grear makes clear the feminist project requires "the capacious visions and activism of feminists and other liberation movements outside the mainstream institutions of law and politics, as well as carving out spaces of resistance and hopefulness on the inside" $(2018,361)$. This requires feminists to consider seriously where they, as an individual, may fall. I will now demonstrate how Radin's theory of the feminist double bind can be harnessed so that engagement or disengagement with mainstream structures can be pursued whilst celebrating plurality and divergence.

\section{Navigating the Feminist Double Bind}

The tension over engaging with, or disengaging from, the mainstream is peppered throughout many key feminist critiques of international law. It is captured within binaries such as "power and danger" (Otto 2010, 97); "resistance and compliance" (Kouvo and Pearson [2011] 2014, 1); "progressive development and dangerous gains" (Heathcote 2018, 374); "victory narratives and danger narratives" (Otto 2014 , 157). Whilst this language is effective in conveying a sense of opportunity and risk for the feminist project in international law, it tends to bracket off the specific tension relating to the international (institutional) order from wider feminist and emancipatory struggles. In keeping with the tone of feminist pasts and feminist futures, I will now look back at Margaret Jane Radin's theory of the feminist double bind (1990, 1699) positing it as a methodological intervention for feminists caught within this tension. I see this theory as offering, not so much a substantive position on feminist engagement/disengagement with international legal institutions, but as a way of seeing the problem as shared across feminisms and social justice projects more broadly. I argue below that both a thin and thick methodological framework can be extrapolated from Radin's theory of bind. The former provides a heuristic for identifying and framing the problem. One can commit to using the bind in this way alone or can build a more explicitly normative argument using the thick reading of the bind.

\section{Locating Feminist Binds: A Thin Reading of Radin}

In her 1990 article The Feminist and the Pragmatist, Radin outlines the core tenets of the double bind which, she argues, continually troubles feminist analysis and prescription. The idea is relatively simple: that a particular feminist ethical problem or source of injustice may give rise to a number of solutions to solve or to mitigate it. In an ideal world, these solutions do not give rise to harm or risk 
of harm, but given the particular social, political and economic context in which we find ourselves, they ultimately do expose us to risk. She argues that it is the nature of oppressive conditions that make feminist strategising fraught, and not necessarily the strategies in and of themselves. Paradoxically then, when the nonideal strategies available are either engaging with a dominant mainstream institution, or disengaging with it to pursue ideal theorising, the latter is still, in effect, a nonideal strategy as it is pursued in response to a nonideal state of affairs.

For the sake of clarity, I will briefly outline the case study that Radin uses to demonstrate the bind in action. She illustratively draws on the, often divisive, issue of sex work to reveal how, when faced with the binary question of legalistion (or decriminalisation) on the one hand, or criminalisation on the other, there is no clear, unified feminist solution. The former route she considers is the 'commodification' prong of the bind, which carries the advantage of allowing sex workers to have full access to, and stronger rights within, the sexual and reproductive market. This ensures that the monetary exchange benefits the 'owners' of the commodity being purchased, which is particularly pertinent given "the current feminisation of poverty and lack of avenues for free choice for women" (1990, 1700). However, Radin argues that this prong risks treating sex workers as fungible market commodities. The alternative 'noncommodification' prong presents similarly interconnected risks and opportunities. If sexual and reproductive capacities are not lawfully available as market commodities, this restricts the extent to which these capacities are treated as "severable fungible objects" (1990, 1700). However, the threat that emerges from this is that women are denied the choice to market their sexual and reproductive services. For Radin, the dual harm which arises within these feminist strategies relate to existing harmful social conditions:

That commodification now tends toward fungibility of women and noncommodification now tends toward their domination and continued subordination are artifacts of the current social hierarchy. In other words, the fact of oppression is what gives rise to the double bind. (1990, 1700)

In this way, feminist strategic endeavors easily become rife with risk and backlash. Seeing that such risks result from nonideal and oppressive social, economic, material, political and legal structures, the question of goal setting forces feminists to consider the extent to which these structures can constrain feminist thought and actions. I see this thin reading of Radin's theory as offering an illuminating heuristic: that feminist's strategic divergence emerges from the prevailing dominant sexed, gendered, racial, classed and ableist hierarchies within legal institutions, and not necessarily feminist ideological divergence per se. This, in and of itself, goes some way in guarding against an impulse one may have to call for feminist uniformity and convergence (Halley [2006] 2008a, 187). Feminist strategic divergence and difference is not the source of the problem, but only appears problematic in light of dominant mainstreams privileging some feminists and some demands. This process plays an important role in instilling a sense of hierarchy within feminism (establishing a 'hegemonic' feminism and its 'Others'), illuminating how power operates within feminist encounters with the mainstream. 
Framing particular feminist tensions in such a way amounts, I argue, to a diagnostic, descriptive practice that explicitly conveys the stakes, both in terms of risks and opportunity, when developing social justice and/or feminist strategies. I find one of the most compelling aspects of this theory lies in its concise framing of an observed pattern of risk and cost, traceable across all manner of social justice struggles against a shapeshifting mainstream. Whilst the risks may stem from power wielded by dominant structures, the bind, even as a diagnostic tool, commits feminists to explicitly outlining the risks or costs embedded within their nonideal strategies. This methodological framework compels sincere, critical self-reflection as the stakes are laid bare.

Radin's theory of the double bind is a particular iteration of her feminist pragmatist methodology which she identified through, and honed within, much of her scholarship on contract law and property rights (see 1987, 1921-1923; 1995a, 140-145; 1996, 123-130; 1999, 1158-1159; 2017, 354-356). I will not discuss here the potential implications of reading the theory of the bind through the lens of these, commercial, transactional legal traditions. ${ }^{1}$ My aim here however is to demonstrate how a descriptive understanding of the feminist double bind sufficiently problematises power and agency in the relations between feminisms and the legal and academic mainstreams. I will now turn to consider the normativity underpinning Radin's contribution, thus offering a thick account of the double bind.

\section{Proceeding with Feminist Binds: A Thick Reading of Radin}

Radin does not just provide a descriptive observation on feminist ethical questions. She offers a pragmatically informed 'way out' of the bind by drawing on theories of nonideal and ideal justice. Having identified the potential strategies that could be taken in answering ethical questions for feminisms (e.g. commodification/noncommodification) one must assess which of the 'prongs of the bind' presents the least bad option. Importantly, the assessment should not be seen as conclusive nor fixed, but temporarily contingent upon nonideal circumstances which constrain the ability to realise ideals. Radin does not provide tools for how such assessments should take place nor does she provide an account of how we should understand 'less bad'. ${ }^{2}$ Rather, by not specifying a particular evaluative approach Radin leaves space for a plurality of methodologies and for the breadth of feminisms' varying priorities and objectives. This space is key to seeing the value for feminisms in her theory, as it is one built on particularities, both of problems and of answers. No singular perspective can be wielded in solving feminist ethical questions. As Radin and Frank Michelman argue: "the field of legal thought contains - arguably - not one

\footnotetext{
1 It is my sense that there is much to say on Radin's use of the bind within her writing on (non)commodification and market (in)alienability in the context of international feminist legal methods. Indeed, it may be interesting, with market inalienability in mind, to consider whether the (neoliberal, neocolonial) international legal mainstream places conditions upon its encounters (transactions) with social justice theories. This would require, however, far greater attention than this paper allows for.

2 I return to discuss this in the context of pragmatism and coherence below.
} 
normativity, but many normativities" $(1991,1023)$. What is taken into account in assessing strategic options relates to the specific problem at hand and the various moving parts which shape it. A plurality of perspectives and normativities reveals varying pieces of truths (in terms of both problems and solutions).

Thus, there are two underlying theoretical streams embedded within Radin's theory: pragmatist-feminism on the one hand, and ideal/nonideal theory on the other. Both of these strands provide the normative principles which undergird the double bind. I will now address each in turn.

\section{Pragmatist-Feminism}

The commitment to plurality within Radin's theory speaks to her position as a pragmatist legal theorist. In evoking the value of different theoretical insight, Radin positions the bind as a counter to unified grand theories which purport to hold the answer to feminist moral questions. In this way, Radin aims to consolidate an underlying commitment which she argues is common to both pragmatism and feminisms; namely embodiment and standpoint as sources of knowing and understanding the world (1990, 1707). The bind is an iterative process which reflects no singular Truth, but allows for piecemeal development, shaped by the multiple (re)evaluative and (re) negotiating processes at play in the face of nonideal circumstances. For Radin this reveals similarities between pragmatist and feminist thought: "If feminists largely share the pragmatist commitment that truth is hammered out piecemeal in the crucible of life and our situatedness, they also share the pragmatist understanding that truth is provisional and ever-changing" (ibid, 1707). The aim of this iterative process is to ultimately dissolve the bind in its entirety (ibid, 1700). This would see the oppressive structures experienced by women, minoritised people, indigenous communities, members of the LGBTIQ+ communities, those with disabilities, individuals from the Global South, and those with intersecting factors of disadvantage, removed. More can be said of the pragmatist-feminism woven within the foundations of Radin's bind and I return to this in discussing objections below. I will now address the other theoretical paradigm within her work: ideal and nonideal theory.

\section{Ideal and Nonideal Theory}

The debt that is owed to theories of ideal and nonideal justice is made explicit in Radin's account. Questions surrounding ideal theorising, in tandem with nonideal feasibility constraints, have been a recurring focus in political philosophy (see Rawls [1971] 1999, 216; Sen 2006; Cohen 2008). Considering this in depth is beyond the scope of this paper. However, the very concise framing of this problem in the space of international law as one of ideal/nonideal tension may offer a much-needed prompt to habitually return to the foundations of feminist ethical dilemmas. Laura Valentini (2012) takes stock of the methodological turn in the political philosophy literature, a turn prompted, she argues, by the "frustration with the subject's perceived lack of influence in real world politics" (2012, 654). She provides a typology of ideal and nonideal justice theories, mapping three interpretations: (i) full compliance versus partial compliance theory; (ii) utopian versus realistic theory; and (iii) 
end-state versus transitionary theory (ibid). Whilst Radin's theory of the bind predates Valentini's typology, the bind is best interpreted as falling within the last of these categories, as Radin sees nonideal justice as informed by ideal theories so that "we know what we are trying to achieve" (1990, 1701). This is not to say that she does not touch upon the utopian versus realistic interpretations. She articulates the bind as a problem of transition, thus the steps taken in light of feasibility are in aid of dissolving the bind in its totality. It is worth noting that there is no clear distinction in Radin's conceptualisation of the bind between utopian versus realistic theory and end-state versus transitionary theory, but it is clear that her normative position emerges from prioritising nonideal justice (transitionary) actions, whilst noting the contingent nature of ideal justice. Thus, ideals are not fixed under her theorising but evolve alongside the nonideal steps we take. In this vein, Radin argues that "our visions and nonideal decisions, our theory and practice, paradoxically constitute each other" (1990, 1701).

There is much that can be gained in considering Radin's diagnosis of the double bind as a helping theorem in considering the tension at the heart of the feminist project in international law. The strategic options of either engaging with international institutions (whilst bearing the risk of cooption) or disengaging to apply pressure from the margins (whilst risking the continuation of exclusion), are the options thrown up by an oppressive, androcentric international order. They are the nonideal measures, loaded with both opportunity and risk, which are juggled with feminist utopias. One does not have to look far to see international legal feminists evoking this way of thinking. Otto's commitment to "juggling critique with hope" (Engle 2017; Otto 2016, 295) enabled her to be critical of the law as is, whilst simultaneously advancing hope for a new legal order. To echo Karen Engles' question: "how else might we imagine peace and the decolonisation of minds and bodies other than by attempting to unravel the knowledge that binds us"? $(2017,122)$. Thus, the ordered chaos of reflexivity and the continual suspension of concluded answers to moral questions embedded within Radin's framework speaks to the methods used by international legal feminists. It holds both ideal and nonideal considerations in mind as one navigates the tensions within, and outside of, a system built on inclusions and exclusions.

I will now show the relevancy of Radin's theory of the double bind for the feminist project in international law by using the UN Security Council, and it's supposed uptake of feminist ideals, as a case study.

\section{Applying the Bind to the UN Security Council}

Feminist tensions over mainstream (dis)engagement is most acute in the context of the Security Council given its "hegemonic reach" (Otto 2009, 12). The Council is the focus of a rich body of cross-disciplinary feminisms: from international law, to international relations, security studies, to institutional studies (see Cockburn 2007; Cohn et al. 2004; Davies 2019; Davies and True 2019; Heathcote 2011; Kirby and Shepherd 2016; Otto 2017; Thomson 2018). I will now outline some of the feminist concerns which have arisen over pursuing social justice objectives through 
the Council. I primarily consider the 'Women, Peace and Security Agenda' (WPS) before demonstrating how the double bind captures much of this critique.

\section{Women, Peace and Security}

Since the Security Council established the WPS through resolution (UNSCR) 1325 (2000), feminist strategies in relation to the Council have been particularly vibrant. The WPS, as a thematic agenda, outlines a normative framework to be operationalised within other streams of the Council's work, such as its country-specific agendas and its peacekeeping mandates (Dornig 2014, 1). In UNSCR 1325 the Council outlines its previous efforts to address the experiences of women in conflict and postconflict settings, however, the substance of UNSCR 1325 marks an important shift in the Council's engagement with feminist ideas. It observes not only the differential impact of conflict on the premise of gender, but also the important contribution of women and girls in peace processes, alongside the need to advance their status and position within society in post conflict settings.

Anne Marie Goetz and Rob Jenkins summarise the fundamental principles laid down in resolution 1325 as:

(1) that gender inequality (in social, economic, and political power) is linked to insecurity; and (2) that successfully preventing, resolving, and rebuilding after conflict requires both women's participation and the incorporation of genderequality concerns, in local, national, and international processes. (Goetz and Jenkins 2018, 119).

These principles can be seen as part of a wider ambition of the UN to obtain gender equality. ${ }^{3}$ This is particularly so given the increasing links made between women's subjugation, and continuing instability and conflict (UN Committee for the Elimination of All Forms of Discrimination Against Women 2013; UN Security Council 2000a, b, c).

The creation of this agenda has been celebrated by those who pressed for a more gender-sensitive Security Council (Otto 2009, 11). The reach of feminist messages could now be considered prolific: influencing the ultimate hegemonic, masculine organ of the UN. Otto argues that this hard-fought achievement saw feminist 'gains' such as: the recognition of "women as full subjects of international law" $(2009,15)$; a feminist foothold for further progress; and the opportunity to politically organise feminist networks, both internationally and locally "creating constituencies outside institutional control" (ibid). Such observations form a part of her "victory narrative", a term she uses in reflecting on her past analytic style of tracing the developments of WPS resolutions (Otto 2014, 158). This victory narrative stands in contrast to her "danger narrative" (ibid), which speaks to the cooption of feminist ideals. The

\footnotetext{
3 The importance of gender equality is stressed in a number of different UN legal instruments, including, inter alia, the Universal Declaration of Human Rights; the International Covenant on Civil and Political Rights; the International Covenant of Economic, Cultural and Social Rights; and the Convention of the Elimination of All Forms of Discrimination Against Women.
} 
weak (or lacking) enforcement mechanisms around the agenda, the perpetuation of protectee (feminine)/protector (masculine) stereotypes, and the selective adoption of feminist ideals, amongst other shortcomings of the WPS, reveal the costs to the feminist project in international law (Otto 2010, 157). Otto has more recently noted that there has been "little feminist debate about the wisdom of engagement with the patently undemocratic and secretive Security Council, the seat of power of the world's superpower(s), whose permanent members are also the world's largest arms dealers" (Otto 2014, 158).

The manner in which Otto has framed the problem is a clear indicator of the feminist double bind at work. By reading her analysis in light of the feminist double bind, even in the thin sense, the strengths of Otto's work is enhanced and more vividly brought to the surface. The costs of engaging or disengaging with the Council are seen as near unavoidable for the feminist, given the background structure of the Council's hegemonic bargaining power, and those costs are made clear, fostering self-reflection and accountability. However, the inverse benefits are also made explicit. Given that the bind embeds nonideal and ideal thinking, it is expected under this methodological framework that different feminist perspectives draw on their ideal, theoretical standpoints to weigh up the nonideal options (the risks and potential benefits). The value of different actors pursuing different routes is made more visible, thus, feminist divergence and plurality is clearly seen as sources of strength for the international legal feminist project. I will now briefly examine some of the ideal theories at work in feminist thought, more specifically on the Council. In so doing, I will demonstrate how engaging with a thick reading of the double bind theory can further feminisms' objectives with the Council in mind.

\section{Unobtained Feminist Ideals at the Security Council}

Shared across the differing strands of feminism lies a commitment to normativity; a tradition which prioritises ethical and political claims as to how the world should be (Srinivasan 2015, 8). Normative ideals, however, are frequently lost or frustrated by feminist encounters with the mainstream. In this way, the histories of feminist struggles are littered with unobtained ideals. By discussing some unobtained ideals of feminisms concerning the Council, I do not seek to promote any particular ideal: it is of course difficult to not explicitly endorse the ideals of peace and equality, but there are various interpretations of precisely what peace and equality require, amongst which I seek to remain neutral (at least here). The rationale for this approach is to provide a frame of reference for the compromises that feminists have made in their interactions with the Council.

These very compromises (or "gains" (Heathcote 2018, 374)) build on, and mirror, the early fault lines carved during the creation of the WPS. Sara Davies and Jacqui True note two underlying tensions with the agenda, the first being the active engagement "with political and economic institutions in order to transform power relations - the very institutions that have marginalised women's representation and livelihoods" (2018). The other tension they observe is that the WPS "has its roots in anti-war women's movements" (ibid), marking a sharp distinction from what we 
see happening with the agenda now: the promotion of mainstreaming gender perspectives within military activities and peacekeeping missions (ibid). The early drivers of peace and anti-militarism underpinned the Women's International League of Peace and Freedom (WILPF) (and the coalition of NGOs which it assembled) efforts to "persuade the Council to adopt a more feminist agenda" (Otto 2018, 107). The initial drafts of the resolution, compiled by this collection of feminist advocates reflected this: centring gender provisions within mandates; strengthening women's existing legal protection and pursuing gender perspectives within Disarmament, Demobilisation and Reintegration programmes; alongside supporting women's local peace building efforts (Cohn et al. 2004, 131-132). However, the resolution which was finally adopted, whilst hailed as groundbreaking, has been criticised for being a watered-down version of WILPF and the NGO coalition's vision (Cockburn 2007, 147). In the compromise of the encounter with the Council, the resolution failed to take seriously ending cycles of conflict, or women's role in preventing them (ibid). The ideals of peace and anti-militarism are now clearly seen as at odds with the trajectory of the agenda (Otto 2018, 107). Otto observes how many of the WPS resolutions do not limit the "justifications for the use of arms" but instead "provide a new trigger for the collective use of force, particularly when sexual violence is used as a "tactic of war"" (Otto 2018, 111). ${ }^{4}$

However, this does not mean that WILPF now rejects the Council's limited feminist vision. On the contrary, the WPS is used by the organisation as a platform for pushing greater reform. In recognition of the 15th-year anniversary of the WPS, WILPF issued a report which, inter alia, highlighted four of its "demands" to the Council (WILPF 2015, 3). Most relevant to this discussion is its third demand: calling for the "stigmatisation of militarism/war...shedding light on the political economy of militarisation" (ibid). This demand very clearly speaks to the 'peace' component of women, peace and security, whilst simultaneously noting the structural obstacle posed to this by a political climate whereby conflict holds currency.

There are, of course, varying degrees of ideals pursued across feminisms. Otto and Grear have most clearly demonstrated this, with Otto arguing that her ideal of "perpetual feminist peace" is a modest goal in contrast to Grear's objectives (2018, 353). In her work Grear challenges the 'Anthropocene' (Otto and Grear 2018, 353-355) and seeks to disrupt the judicially privileged centrality of human agency, which she argues facilitates legally constructed hierarchies, exiling "non-European 'others', feminised others, queer and 'irrational' others, including the indigenous - but also the "animal"' (ibid). Not only does this conversation demonstrate the very different versions of a feminist utopia that exist, but it reveals the extent to which feminist objectives are frustrated through any efforts to channel these aims through the non-ideal mechanisms of international, inter-State institutions. For Otto, simply fusing frames of "peace" to frames of "security" (which is clearly visible in the very name of the Council's WPS) can only lead to a "dirty" and militarised form of peace, and perpetual cycles of conflict and insecurity (Otto 2018, 115). Similarly, Heathcote, amongst others, has argued that the recent merging of the WPS with the

\footnotetext{
${ }^{4}$ The Security Council resolutions Otto refers to here are: 1820 (2008); 1888 (2009) and 1960 (2010).
} 
Council's counter-terrorism framework underlines why the institution cannot be seen as a space for progressing the feminist agenda (2018, 375; Chowdhury Fink and Davidian 2018, Ní Aoláin 2016). Heathcote notes that the continued silence of the Council on its increasing record of authorisations of military action, and its silence on the complicity of UN peacekeeping missions in the sexual exploitation and abuse of women and girls, raises important questions as to the Council's feminist credentials $(2018,375)$. In these conversations, the underlying tension between nonideal feasibility constraints and ideal theorising, upon which the double bind rests, can be traced. Radin's theory has the virtue of bringing into particularly sharp focus the trap of engaging with, or disengaging from, the mainstream and offers a structure for furthering these conversations.

\section{The Bind in Action}

I will now map out, more specifically, how the bind applies to the UN Security Council. I will show how the bind as a methodological tool enables feminists to explicitly contextualise available strategies and the risks embedded within them. This explicit contextualisation guards against pursuing strategies uncritically or in an unreflective way. It embeds a critical pragmatism within feminist thinking, and a humble acceptance of the contingency of feminist knowledges upon the individuals situated temporal world views.

The strategic options available when it comes to the Council have long been discussed. Otto most clearly captures them by pointing to the tension between celebrating the positive wins of engagement on the one hand and warning of danger on the other $(2010 ; 2017)$. Should feminists be pursuing a narrow form of 'victory' and 'power' or should they be resisting this? (Otto 2014). Are they even required to comment on this tension, and their position in relation to it, within their analysis? This tension has become so entrenched within parts of the feminist consciousness that it is seen as important to not only recognise it, but to also nail one's colours to the mast. In Tamsin Phillipa Paige's recent analysis of Security Council debates on sexual violence she explores the lens of heteronormativity (2018). Emily Jones, whilst remarking on the strength in Paige's normative stance on inclusivity outside of the heteronormative matrix, notes her silence on the overarching tension (Jones 2019, 117). Jones argues that the analysis "leaves the reader wondering what the author's own stance is, [given] the background debates on feminist and queer alliances with security inherently framing the structure of inclusion and exclusion" (ibid). Clarifying whether you target your critique and your normative contributions towards the mainstream or the margins is therefore key. To do so, whilst using the double bind as a theoretical framework, reveals an awareness of the nonideal nature of your choice.

The double bind allows feminists to see both engaging and disengaging as the nonideal strategies which have been made available to them by an exclusionary and oppressive structure. The choices that are made do not exculpate the source of this structural violence. Having a choice does, however, place a responsibility on feminists to evaluate the options and to determine which is the least bad. María Martín de Almagro work demonstrates the racial, classist, heteronormative and 
Western-centric structure of the WPS through a postcolonial analysis of national action plans (2018). She shows that when the WPS is instrumentalised at the national level, particular subject positions relating to gender, race, and class become normalised and fixed in a hierarchical way, embedding inequalities $(2018,404)$. Yet to abandon the framework of the WPS may perpetuate the exclusion that the underpinning feminist aspirations of the agenda sought to counter. These risks frame the nonideal nature of the strategies available, tying them to the overarching structures of the exclusionary nature of dominant mainstreams. With this knowledge, having taken Martín de Almagro analysis on board, a feminist subject can choose whether to engage with the Council (seeing it as having the potential to upend such hierarchies) or disengage (seeing it as conserving, rather than tackling, the status quo). The explicit nature of the bind embeds accountability and self-reflection in the process of weighing up which nonideal option is the least bad. Importantly though, this decision should be knowingly flexible, with any final judgment suspended. To engage with the double bind in a thick way, the theory compels working on both ideal and nonideal theorising alongside each other. This fuels the coevolution of "our institutions, our ideals and ourselves" (Radin 1995b, 1600), enabling the betterment of the institutions, and therefore the nonideal options available, as feminists outgrow their situated insights and critiques (ibid, 1599).

\section{Challenges}

This paper has shown how Radin's work on the double bind offers a valuable methodological insight to the fundamental tension at the heart of international legal feminisms. I will now consider two possible objections to the arguments which I have advanced: first, that it may entrench binary thinking within international feminism; and second, that the pragmatism drawn on may diminish radical and revolutionary feminist ambitions. I will do so by drawing on some of Radin's own defences embedded within her work, whilst enhancing them in light of recent trajectories of feminisms.

\section{Binds and Binaries}

Potentially the most obvious cause for objection is the very bind at the core of my argument. It may be questioned whether a binary can be dissolved in the process of centring binary tensions such as resistance and compliance, and engagement and disengagement. As feminists we tend to find ourselves concerned by reductive binaries, such as the public/private divide, which funnel all of life's complexity into one category or another (Lacey 1993, 94; Charlesworth and Chinkin 2000, 49-50). We rally against the simplistic construction of gender as either man or woman, male or female, and we attempt to release the straitjacket of prescriptive and proscriptive legal norms constructed around seemingly watertight categories of lived experiences (Lacey 1993, 103-107; Drakopoulou 2000, 200; Heathcote 2019, 3). Thus, any theory which appears to prescribe binary thinking 
as offering an answer may raise alarm bells for those with feminist intuitions. The binary thinking embedded within Radin's original piece may be thought to simplify a number of complex issues, reducing the potential feminist responses to two, e.g. commodification/noncommodification; resistance/compliance; engagement/disengagement. This may be considered unsatisfactory, with binary options seeming crude and reductive. Radin does not explicitly consider such an objection, however, I have extrapolated two defences built into her argument. The first concerns the dissolution of the bind, and the second is rooted in her general arguments on feminist and pragmatist thought.

Turning to consider the first defence, Radin appears to address the potentially reifying effects of describing binds by using prescriptive reasoning: that is, by advancing a normative framework for what to do when a bind is identified. Radin argues that the bind does not need solving, but dissolving (1990, 1700). I see the two prongs of action Radin identifies for doing so as the pathways thrown up by a legal system built on the assumption of unified, masculine subjects (Drakopoulou 2000, 200; Kapur 2005; Heathcote 2019, 96-102) which are seen to navigate a world divided between legality and illegality, regulated and unregulated (Lacey 1993, 94). The law brings to life a world of binary options. Feminists are therefore faced with a decision between adopting the tools of the law to 'fix' moral questions, or to turn their backs on this framework, and build critique which rejects the law as holding the answer. Even when there appears to be more than two options, they will often share structural features which make it useful to categorise them as under one of two headings. For example, there may be various ways in which we engage with the mainstream or operate from the margins, in the same way that the approaches to legal regulation may be varied. However, such options are still captured within the binary terms of engagement or disengagement with the legal processes wielded by the mainstream. It is because of this structuring process that feminists find themselves faced with simplistic, nonideal binds which obscure the diversity of experience and push subjectivities to the peripheries (Kapur 2005, 3).

The dissolution of the bind is, of course, an end goal, but a critic may still see this as an insufficient justification for the process of describing such binds. Such a practice may be more damaging than not, serving to (re)constitute binds and therefore entrench inequality. This is the risk of appearing to hold on to, and maintain, outsider status from the mainstream through feminist description. Paradoxically, through describing feminist problems as such, the 'ghettoisation' of 'women's issues' is maintained (Bianchi 2016, 201). In many ways, this is a cost of the nonideal measure of describing problems: feminisms may indeed contribute to reifying them. Herein lies the fundamental challenge for feminist and social justice projects in describing the world as is alongside developing a normative account for how the world should be (Srinivasan 2020, 39; Srinivasan 2015). Radin's theory commits feminists to being explicit in the nonideal nature of their binary options, but this thin reading of the bind centres on the task of description. Of course, feminists, in addressing a problem, need to be able to see it and name it before doing so. In outlining the commodification/noncommodification bind, Radin engages in the same practice as Kouvo and Pearson ([2011] 2014) in outlining the compliance/resistance bind. So how can the potential 
damage of description be squared with revolutionary end goals which upend the hierarchies which feminism may be accused of partly constituting through description?

This is where Radin's work on anti-normative critique (poststructuralism), feminism and pragmatism can be useful. In drawing on the similarities between feminism and more traditional modes of pragmatism (such as those espoused by William James and John Dewey), Radin observes that both commit to the dissolution of traditional dichotomies, and the methodology of consciousness raising as a way out of inequality and oppression (1990, 1707-1708). Description here can be read as communicating "shared meaning out of shared interactions with the world" (ibid, 1708). For Radin, pragmatism and feminism alike "must make communication possible where before there was silence" (ibid). Thus, describing feminist ethical problems is an advance upon ignorance of one's own exclusion. However, even in this defence, the bind appears to be at play, simmering under the surface. Speaking, as describing, and not speaking at all is dichotomous: these options could be categorised as engagement/disengagement. The pragmatic line of thinking in Radin's bind suggests that feminists cannot do the impossible and insists upon bracketing off fundamental tensions. For example, she argues that "conventional femininity", marked as traditional exclusion from the masculine world of public institutions, "is where we start, it is what we have to work with" (Radin and Michelman 1991, 1051). Part of the feminist process is "the watchful receptiveness to redescription. It is the cultivated understanding that all our old descriptions of the world are always open to progressive change" (ibid).

A further way to defend against this critique is to deemphasise the conceptual split between description and normativity. If describing binds is problematic, it is helpful to consider the subtle prescription within, even the most straightforward of descriptive utterances. Whilst I have argued that there is both a thin and thick reading that can be extrapolated from the feminist double bind, these categorisations are rough approximations. It is not that descriptive or normative work is all that they are doing, but more where the emphasis of them lies. Ostensibly the normative component sees the feminist as advancing alternative realities to the bind, it compels an explicit engagement with ideal theory, but to a lesser degree so too does the descriptive component of the bind. In writing on the anti-normativity pursued by some forms of legal positivism, Radin and Michelman deny the possibility of separating communicative acts such as description, normativity (or prescription) and criticism $(1991,1027)$. For them, communication delivers an argument, even implicitly, for how one should see the world. They argue there is "no non-normative utterance. There are only kinds and degrees of normativity" (ibid). Amia Srinivasan similarly troubles the supposed value-free descriptive processes valued in mainstream philosophical enquiry. She argues that feminist philosophy is simply more explicit about the inseparability of descriptive and prescriptive inquiry, as she charges mainstream philosophers with "pursu[ing] prescriptive project[s] under the guise of descriptive one[s]" $(2015,14)$. Thus, even the more descriptive aspect of framing double binds embeds a normativity that works against the bind itself. 


\section{Coherence, Conservatism and Ideal Thinking}

The second objection I consider relates to the bind's reliance upon pragmatic reasoning. A critic may harbour reservations surrounding the potentially conservative nature of this theoretical tradition, particularly in contrast to the more revolutionary and critical tenets of international legal feminisms. It is worth noting that conveying the wider corpus of feminist-pragmatist thought is beyond the scope of this paper. What I address here are those issues directly relevant to the double bind. Whilst this theory is entangled within the pragmatic tradition, it would be too quick to interpret the arguments herein as a call for a wholesale adoption of feminist-pragmatist method. Future research which considers, for example, the contemporary contribution of Black feminist pragmatist theorising (see James and Busia 1993; James 2009), or feminist reinterpretations of classic pragmatic writings of Dewey and Jane Addams (see Fischer 2000; James 2017), could consider such questions. In regard to conservatism, Radin herself demonstrates how to avoid such an interpretation of the bind and I will address this in the first instance before expanding on how ideal theory can further guard against this.

\section{Conservative Pragmatism}

There is still the question of determining which prong of the bind is the least bad. Whilst Radin remains relatively open on this, she introduces a particular criterion for making value judgments: coherence, both in terms of conceptual coherence and institutional coherence $(1990,1705)$. However, such a yardstick may prevent efforts to effect radical change. By 'coherence', Radin refers to the way in which pragmatist theories have conceived of truth and knowledge: that they emerge in a piecemeal way from situated experiences $(1990,1707)$. She further explains that "when we are faced with new experiences and new beliefs, we fit them into our web [of knowledge and truth] with as little alteration of what is already there as possible" (1990, 1709). When faced with two nonideal options, such an understanding of truth discounts the option which looks less like the coherent system that we currently have. Thus, a pragmatist may place more value on the nonideal path which alters the web of knowledge the least. Feasible options under the 'compliance' prong hold greater weight under this model of evaluation for being more readily accommodated into the mainstream. This is notably a conservative method and is particularly unsatisfactory in the case of 'bad coherence', where a coherent system of belief exists but it is marked by domination and oppression (Radin 1990, 1710). The paradoxical question for Radin is "how can the pragmatist find a standpoint from which to argue that a system is coherent but bad, if pragmatism defines truth and good as coherence?" (1990, 1710).

In the context of legal governance structures, a conservative approach to coherence which privileges strategies that fit in with institutional values, customs and principles may prevail over more radical, revolutionary strategies by virtue of their feasibility. For the conservative pragmatist, gender mainstreaming may appear less bad in that it offers institutional coherence. In this way, the bind works to maintain the existing status quo. An international legal system which is coherently 
exclusionary will attract, in the search for continued coherence, strategies that offer only partial, limited inclusion, while maintaining exclusionary practices. What this means, Radin notes, is that "for the oppressed...the status quo must change very slowly, if at all" (1990, 1722). This may be too unsatisfactory for those approaching the problem from more revolutionary and radical viewpoints.

Radin does go some way in offering a solution for the pragmatist-feminist. She argues "[they] must find a way that 'the law' can be understood to include the conceptions of the oppressed as they are coming to be, even if the weight of legal institutions coherently excludes them" (1990, 1721). Radin argues that releasing the chains of conservative, institutional coherence can be achieved through listening to the perspectives of disadvantaged or oppressed groups and allowing more give to the embedded plurality in legal interpretation (ibid; 1724-1725). Legal processes are inherently pluralist: from advocacy, to drafting, to interpretation, individuals may come to different conclusions as to how to affect law. The "critical spirit of pragmatism" (ibid, 1725) lies in the fostering of marginal voices within legal procedures, much like the critical spirit of feminisms. Such thinking can be uncovered from the surface of international legal feminist analysis of the WPS. The footholds of feminist engagement, Otto argues, stem from the concrete (albeit precarious) legal inroads of the Security Council's WPS $(2010,120)$. This allows for the continual interpreting and reinterpreting of legal norms from various theoretical perspectives which can effectively disrupt patterns of institutional coherence which maintain exclusion. The critical spirit of the double bind, therefore, can only be realised when critical insights are advanced. Feminisms are rich sources of such insight. Through their divergent plurality and elevating of peripheral subjectivities, feminisms are acutely embedded within, what Otto calls, the "politics of listening" (Otto 2017; Heathcote 2019, 194).

This may not wholly guard against conservative assumptions of the pragmatic underpinnings of the bind. The conceptualisation of the bind as a continual, reoccurring choice between two nonideal conditions may appear to present nonideal justice as an inevitability; as the feminist's 'lot'. When this is paired with coherence as a pragmatic evaluative yardstick, there could be concern that the bind's pluralist critical spirit may all to easily be overrun in the context of a legal tradition which holds institutional cohesion at its core. Maria Grahn-Farley has raised concern over a strand of feminist thinking which lends itself to the "politics of inevitability" (Grahn-Farley [2011] 2014, 109; Halley 2008b). Grahn-Farley criticises Halley for using agency theory "as a way for the individual to make peace with her lot by willingly accepting the oppressive effects of the institution" ([2011] 2014, 121). Victimhood is diminished under this account. She goes on to argue that when oppression is taken as inevitable, and is legitimised by theories which aim to undermine the victim's status by demonstrating their ability to choose, "agency theory, as it passes through the politics of inevitability, becomes a new form of sexism and anti-feminism" (ibid). The bind rests on an assumption that the feminist is able to exercise choice in which nonideal option to take. The feminist, having freedom to choose between engaging or disengaging with legal institutional and academic mainstreams, is read as privileged and should be thankful for being given options. However, this attributes too much to agency theory, obscuring the degree and effect 
of mainstream, institutional exclusion on feminists. Such an interpretation fetishises the limited movement available to the feminist. To guard against this, one needs to look to ideal theory to demand better options.

\section{Pursuing Ideal Feminisms}

Centring ideal theories and feminist commitments whilst navigating the double bind is key to ensuring that nonideal considerations and ideal imaginings continually speak to each other, coevolve and effect fundamental change on the various mainstreams. To do this, I stress a departure from imagining fixed, external utopian worlds, and instead adopt utopian thinking in using the double bind. I understand utopian thinking as a cyclical process of using ideal theory as a means to evaluate nonideal options. In this way, normative principles are used to assess nonideal realities, which in turn hone the normative principles developed. This process mitigates the bifurcation of ideal theory from nonideal realities: where on the one hand there is a utopian world of both "no place" and the "good place" (Cooper 2014, 5), and on the other hand, a realist world of feasibility constraints.

Returning to Valentini's taxonomy of ideal and nonideal theories (2012), it is a reminder of Radin's double bind being a "a problem of transition" (1990, 1701). This positions her work firmly within the 'end-state vs. transitionary' interpretation of ideal/nonideal theory. Under this understanding, ideal theories develop normative principles for the 'end-state', whilst nonideal thinking tells one how to achieve this end-state gradually. However, as I outlined above, Radin's theory also strays into Valentini's utopian versus realist forms of theorising. Drawing on the work of G. A. Cohen, Valentini reveals how this conceptual framing places less emphasis on the normative aspect of the ideal prong, and more on its evaluative potential $(2012,5$; Cohen 2003; 2008). The utopian versus realist framing is less concerned with developing rules on what one should $d o$, and more concerned with how one should think (Valentini 2012, 5; Gilabert 2011, 58), and in particular, how to determine whether something is good or bad.

The evaluative potential of utopian thinking guards against conservative pragmatism as it moves us away from imagining utopias and normative principles which are overly responsive to the feasibility constraints of the world as is. Davina Cooper warns against developing normative concepts which emerge from, and are thus grounded in, the established mainstream $(2014,29)$. She argues that this renders them "stuck" with the effects of dominant practices $(2014,29)$. To refer back to Radin's web analogy of pragmatic coherence, ideals are like butterflies: vulnerable to the sticky spider web of institutional practice. The task of evaluation exists in the space between the imaginings of ideals and the sticky feasibility constraints of actualisation (Cooper 2014, 13). Anca Gheaus posits that prescriptive or normative claims invoke the "ought implies can" principle $(2013,457)$. She argues for a conception of justice which is detached from feasibility but still responsive to the prevailing state of affairs: "while issues of feasibility are relevant to limiting the scope of agent's duties, they are not relevant to determining the content of the concept of justice" $(2013,449)$. She draws on Pablo Gilabert's distinction between normativity and evaluations arguing that the former is contingent upon feasibility whereas the 
latter is not (2013, 447; Gilabert 2011). Thus, when feminists evaluate international legal institutions they can do so in relation to feminist ideals as evaluative yardsticks. This is even as they navigate the feasibility constrained bind of nonideal options. Institutional coherence may be a valuable yardstick for, say, conservative versions of pragmatism, but it is unlikely to be a valuable yardstick for a more critical pragmatist, or a revolutionary feminist. Ideal theorising provides space to develop evaluative tools and refine the values which are used to call for change. In this way one can "consider further strategies of reconstruction (and disruption) within the structures of the global order" (Heathcote 2016, 133) whilst managing ideal visions and nonideal realities. Such management embeds a practice of oscillation within feminisms from the feasibility constraints of the nonideal circumstances, to the revolutionary realm of the ideal, etching out, along the way, the coevolution and betterment of these prongs.

\section{Conclusion}

The historical tension at the heart of feminisms, and other social justice theories, in their interactions with institutions of power is seemingly an ever-vexing issue to which international legal feminism is not immune. Key proponents in the field have called for a return to our methodological processes, and in answering this call, I have argued for the need to stop and take stock of where we have been and where we plan on going in our various feminist futures. In considering whether we are living in a time of 'beautiful chaos', I turned to the work of Radin to conceptualise a way to foster plurality in managing guilt and expectations of nonideal strategies. As one struggles over how to see oneself, as a feminist using the tools of traditional doctrinal analysis and legal argumentation to cultivate change from the inside or as a feminist engaged in a deeper, more fundamental critical analysis from the outside in rejection of the existing framework, guilt may follow. The risk of legitimising and propping up systems of oppression as they coopt social justice movements on the one hand, or giving up on the victories of past feminisms and being rendered irrelevant, on the other hand, can produce paralysis. Whether feminists choose complicity or resistance they are held hostage to the feasibility constraints of the existing oppressive conditions maintained by governance institutions. The continual process Radin posits of deciding and redeciding which is the least bad option goes some way in ensuring humility in framing situated knowledges. By fostering the perspectives of the oppressed through the inroads that feminisms have already produced we can speed up transformation, drawing closer to ideals, and dissolving the oppressive bind more quickly. Crucially, feminist ideal theorising is to be centred within such argumentation structures and I have offered one possible way to think about developing evaluative principles for advancing nonideal realities.

This may not be "a time when injury, suffering, indignity, symbolic, material violence, injustice, hunger, poverty are terms that conjure up times gone by" (Anonymous in Kouvo and Person [2011] 2014, 218). But a time when we hold our knowledges in suspense, oscillate between nonideal strategies and ideal theorising, when we understand and forgive each other and ourselves for the risks we inevitably take 
in our nonideal world, seek out plurality of perspectives and resist assimilating our identities within the mainstream, which looks like an increasingly beautiful and chaotic future for the feminist project in international law.

Acknowledgements I am grateful to Lawrence Hill-Cawthorne and Aleardo Zanghellini for their ongoing supervision and patience as I wrestled with the methodology chapter of my PhD for too long, resulting in this paper. For their written comments and suggestions on recent drafts I thank Africa Bauza Garcia-Arcicollar, Jamie Draper and Alex McLaughlin. I am grateful for the considered comments from the two anonymous reviewers and the editorial board at Feminist Legal Studies. This paper stems from my $\mathrm{PhD}$ research, funded by the Arts and Humanities Research Council (Grant No. 1796597) via the South, West and Wales Doctoral Training Partnership. It is a pleasure to acknowledge their support.

Open Access This article is licensed under a Creative Commons Attribution 4.0 International License, which permits use, sharing, adaptation, distribution and reproduction in any medium or format, as long as you give appropriate credit to the original author(s) and the source, provide a link to the Creative Commons licence, and indicate if changes were made. The images or other third party material in this article are included in the article's Creative Commons licence, unless indicated otherwise in a credit line to the material. If material is not included in the article's Creative Commons licence and your intended use is not permitted by statutory regulation or exceeds the permitted use, you will need to obtain permission directly from the copyright holder. To view a copy of this licence, visit http://creativecommons.org/licen ses/by/4.0/.

\section{References}

Bianchi, Andrea. 2016. International Law Theories: An Inquiry into Different Ways of Thinking. Oxford: Oxford University Press.

Charlesworth, Hilary. (2011) 2014. Talking to Ourselves? Feminist Scholarship in International Law. In Feminist Perspectives on Contemporary International Law: Between Resistance and Compliance?, ed. Sari Kouvo and Zoe Pearson, 17-32. Oxford: Oñati International Series in Law and Society, Hart Publishing.

Charlesworth, Hilary, and Christine Chinkin. 2000. The Boundaries of International Law: A Feminist Analysis. Manchester: Manchester University Press.

Charlesworth, Hilary, Christine Chinkin, and Shelley Wright. 1991. Feminist Approaches to International Law. American Journal of International Law 85 (4): 613-645.

Charlesworth, Hilary, Gina Heathcote, and Emily Jones. 2019. Feminist Scholarship on International Law in the 1990s and Today: An Inter-Generational Conversation. Feminist Legal Studies 27 (1): 79-93.

Cockburn, Cynthia. 2007. From Where We Stand: War, Women's Activism and Feminist Analysis. London: Zed Books.

Cohen, G.A. 2003. Facts and Principles. Philosophy \& Public Affairs 31 (3): 211-225.

Cohen, G.A. 2008. Rescuing Justice and Equality. London: Harvard University Press.

Cohn, Carol, Helen Kinsella, and Sheri Gibbings. 2004. Women, Peace and Security: Resolution 1325. International Feminist Journal of Politics 6 (1): 130-140.

Convention on the Elimination of All Forms of Discrimination Against Women (adopted 18 December 1979, entered into force 3 September 1981) 1249 UNTS 13 (CEDAW).

Cooper, Davina. 2014. Everyday Utopias: The Conceptual Life of Promising Spaces. USA: Duke University Press.

Crenshaw, Kimberlé. 1991. Mapping the Margins: Intersectionality, Identity Politics, and Violence Against Women of Color. Stanford Law Review 43 (6): 1241-1299.

Davies, Laura. 2019. Women, Peace and Security: Adrift in Policy and Practice. Feminist Legal Studies 27: 95-107.

Davies, Sara E, and Jacqui True. 2018. From Pillars to Progress in Women, Peace and Security. London School of Economics Blog. https://blogs.lse.ac.uk/wps/2018/11/26/from-pillars-to-progress-inwomen-peace-and-security/. Accessed 13 Aug 2020. 
Davies, Sara E., and Jacqui True (eds.). 2019. The Oxford Handbook of Women, Peace and Security. New York: Oxford University Press.

Dornig, Swen. 2014. Permanent Mission of Liechtenstein to United Nations, Liechtenstein Institute on Self-Determination Commentary. Supporting the UN Security Council in Applying its Thematic Agendas to its Country-Specific Work. https://lisd.princeton.edu/file/291/download?token=7bPb5 41G. Accessed 13 Nov 2018.

Drakopoulou, Marie. 2000. The Ethic of Care, Female Subjectivity and Feminist Legal Scholarship. Feminist Legal Studies 8 (2): 199-226.

Engle, Karen. 2017. Juggling Critique with Hope. Melbourne Journal of International Law 18 (2): $120-122$.

Fink, Chowdhury, Naureen, and Alison Davidian. 2018. Complementarity and Convergence? Women, Peace and Security and Counterterrorism. In The Oxford Handbook of Gender and Conflict, ed. Fionnuala Ní Aoláin, Naomi Cahn, Dina Francesca Haynes, and Nahla Valji, 157-170. New York: Oxford University Press.

Fischer, Marilyn. 2000. Jane Addam's Feminist Ethics. In Presenting Women Philosophers, ed. Cecile T. Tougas and Sara Ebenreck, 51-58. Philadelphia: Temple University Press.

Gheaus, Anca. 2013. The Feasibility Constraint on the Concept of Justice. The Philosophical Quarterly 63 (252): 445-464.

Gilabert, Pablo. 2011. Debate: Feasibility and Socialism. Journal of Political Philosophy 19 (1): 52-63.

Goetz, Anne Marie, and Rob Jenkins. 2018. Participation and Protection: Security Council Dynamics, Bureaucratic Politics, and the Evolution of the Women, Peace and Security Agenda. In Handbook of Gender and Conflict, ed. Fionnuala Ní Aoláin, Naomi Cahn, Dina Francesca Haynes, and Nahla Valji, 119-131. New York: Oxford University Press.

Grahn-Farley, Maria. (2011) 2014. The Politics of Inevitability: An Examination of Janet Halley's Critique of the Criminalisation of Rape as Torture. In Feminist Perspectives on Contemporary International Law: Between Resistance and Compliance?, ed. Sari Kouvo, and Zoe Pearson, 109-129. Oxford: Oñati International Series in Law and Society, Hart Publishing.

Halley, Janet. (2006) 2008a. Split Decisions: How and Why to Take a Break from Feminism. Oxford: Princeton University Press.

Halley, Janet. 2008b. Rape in Berlin: Reconsidering the Criminalisation of Rape in the International Law of Armed Conflict. Melbourne Journal of International Law 9: 78-124.

Halley, Janet, Prabha Kotiswaran, Hila Shamir, and Chantal Thomas. 2006. From the International to the Local in Feminist Legal Responses to Rape, Prostitution/Sex Work, and Sex Trafficking: Four Studies in Contemporary Governance Feminism. Harvard Journal of Law and Gender 26: 335-423.

Halley, Janet, Prabha Kotiswaran, Rachel Rebouché, and Hila Shamir (eds.). 2018. Governance Feminism: An Introduction. Minneapolis: University of Minnesota Press.

Halley, Janet, Prabha Kotiswaran, Rachel Rebouché, and Hila Shamir (eds.). 2019. Governance Feminism: Notes from the Field. Minneapolis: University of Minnesota Press.

Harris Rimmer, Susan, and Kate Ogg (eds.). 2019. Research Handbook on Feminism Engagement with International Law. Cheltenham: Edward Elgar Publishing.

Heathcote, Gina. 2011. Feminist Politics and the Use of Force: Theorising Feminist Action and Security Council 1325. Socio-Legal Review 7: 23-43.

Heathcote, Gina. 2018. Security Council Resolution 2242 on Women, Peace and Security: Progressive Gains or Dangerous Development? Global Society 32 (4): 374-394.

Heathcote, Gina. 2019. Feminist Dialogues on International Law: Successes, Tensions, Futures. Oxford: Oxford University Press.

Hodson, Loveday, and Troy Lavers (eds.). 2019. Feminist Judgments in International Law. Oxford: Hart Publishing.

hooks, bell. 1984. Feminist Theory: From Margin to Centre. Boston: South End Press.

International Covenant on Civil and Political Rights (adopted 16 December 1966, entered into force 23 March 1976) 999 UNTS 171 (ICCPR), preamble, art 3.

International Covenant on Economic, Social and Cultural Rights (adopted 16 December, entered into force 3 January 1976) 993 UNTS 3 (ICESCR) preamble, art 3.

James, V.Denise. 2009. Theorising Black Feminist Pragmatism: Forethoughts on the Practise and Purpose of Philosophy as Envisioned by Black Feminists and John Dewey. The Journal of Speculative Philosophy 23 (2): 92-99.

James, V.Denise. 2017. Feminist Pragmatism. In The Routledge Companion to Feminist Philosophy, ed. Ann Garry, Serene J. Khader, and Alison Stone, 132-142. New York: Routledge. 
James, Stanlie M., and Abena P.A. Busia (eds.). 1993. Theorizing Black Feminisms: The Visionary Pragmatism of Black Women. London: Routledge.

Jones, Emily. 2019. Dianne Otto (ed): Queering International Law: Possibilities, Alliances, Complicities, Risks. Feminist Legal Studies 27 (1): 115-120.

Kapur, Ratna. 2005. Erotic Justice: Postcolonialism, Subjects and Rights. London: The Glass House Press.

Kapur, Ratna. 2018. Gender, Alterity and Human Rights: Freedom in a Fishbowl. Cheltenham: Edward Elgar Publishing.

Kirby, Paul, and Laura J. Shepherd. 2016. The Futures Past of the Women, Peace and Security Agenda. International Affairs 92 (2): 373-392.

Kouvo, Sari, and Zoe Pearson, eds. (2011) 2014. Feminist Perspectives on Contemporary International Law: Between Resistance and Compliance? Oxford: Oñati International Series in Law and Society, Hart Publishing.

Lacey, Nicola. 1993. Theory into Practice? Pornography and the Public/Private Dichotomy. Journal of Law and Society 20 (1): 93-113.

Martín de Almagro, María. 2018. Producing Participants: Gender, Race, Class, and Women, Peace and Security. Global Society 32 (4): 395-414.

Ní Aoláin, Fionnuala. 2016. The 'war on terror' and Extremism: Assessing the Relevance of the Women, Peace and Security Agenda. International Affairs 92 (2): 275-291.

Otto, Dianne. 2009. The Exile of Inclusion: Reflections on Gender Issues in International Law over the Last Decade. Melbourne Journal of International Law 10: 11-26.

Otto, Dianne. 2010. Power and Danger: Feminist Engagement with International Law Through the UN Security Council. Australian Feminist Law Journal 32 (1): 97-121.

Otto, Dianne. 2014. Beyond Stories of Victory and Danger: Resisting Feminism's Amenability to Serving Security Council Politics. In Rethinking Peacekeeping, Gender Equality and Collective Security, ed. Gina Heathcote and Dianne Otto, 157-172. London: Palgrave Macmillan.

Otto, Dianne. 2016. Impunity in a Different Register: People's Tribunal and Questions of Judgment, Law, and Responsibility. In Anti-impunity and the Human Rights Agenda, ed. Karen Engle, Zinaida Miller, and D.M. Davis, 291-328. Cambridge: Cambridge University Press.

Otto, Dianne. 2017. Beyond Legal Justice: Some Personal Reflections on People's Tribunals, Listening and Responsibility. London Review of International Law 5 (2): 225-249.

Otto, Dianne. 2018. Women, Peace and Security: A Critical Analysis of the Security Council's Vision. In The Oxford Handbook of Gender and Conflict, ed. Fionnuala Ní Aoláin, Naomi Cahn, Dina Francesca Haynes, and Nahla Valji, 105-118. New York: Oxford University Press.

Otto, Dianne, and Anna Grear. 2018. International Law, Social Change and Resistance: A Conversation Between Professor Anna Great and Professorial Fellow Dianne Otto. Feminist Legal Studies 26 (3): 351-363.

Paige, Tamsin Phillipa. 2018. The Maintenance of Heteronormativity. In Queering International Law: Possibilities, Alliances, Complicities, Risks, ed. Dianne Otto, 91-109. New York: Routledge.

Radin, Margaret Jane. 1990. The Pragmatist and the Feminist. Southern California Law Review 63: 1699-1726.

Radin, Margaret Jane. 1995a. What, if Anything, is Wrong with Baby-Selling. Pacific Law Journal 26: $135-145$.

Radin, Margaret Jane. 1995b. Positive Theory as Conceptual Critique: A Piece of a Pragmatic Agenda? Southern California Law Review 68: 1595-1603.

Radin, Margaret Jane. 1996. Contested Commodities: The Trouble with Trade in Sex, Children, Body Parts, and Other Things. London: Harvard University Press.

Radin, Margaret Jane. 1999. Human, Computers and Binding Commitment. Indiana Law Journal 75 : 1125-1162.

Radin, Margaret Jane. 2017. From Baby-Selling to Boilerplate: Reflections on the limits of the infrastructures of the Market. Osgoode Hall Law Journal 54: 339-376.

Radin, Margaret Jane, and Frank Michelman. 1991. Pragmatist and Poststructuralist Critical Legal Practice. University of Pennsylvania Law Review 139: 1019-1058.

Rawls, John. (1971) 1999. A Theory of Justice. Oxford: Oxford University Press.

Sen, Amartya. 2006. What Do We Want from a Theory of Justice? Journal of Philosophy 103 (5): $215-238$.

Spivak, Gayatri Chakravorty. 1988. Can the Subaltern Speak? In Marxism and the Interpretation of Culture, ed. Nelson Cary and Grossberg, 271-316. Illinois: University of Illinois Press. 
Srinivasan, Amia. 2020. He, She, One, They, Ho, Hus, Hum, Ita. London Review of Books 24 (13): 34-39.

Srinivasan, Amia. 2015. Does Feminist Philosophy Rest on a Mistake? Kings College London Key Note. http://users.ox.ac.uk/ corp1468/Research_files/Does\%20Feminist\%20Philosophy_KCL\%20tal k.pdf. Accessed 6 July 2020.

Thomson, Jennifer. 2018. The Women, Peace and Security Agenda and Feminist Institutionalism: A Research Agenda. International Studies Review 17: 1-16.

UN Committee for the Elimination of All Forms of Discrimination Against Women, 'General Recommendation Number 30 on Women in Conflict Prevention, Conflict and Post-Conflict Situations' (18 October 2013) UN Doc CEDAW/CG/30.

UNGA Res 70/1 (21 October 2015) UN Doc A/RES/70/1 (SDGs) goal 5.

Universal Declaration on Human Rights (adopted 10 December 1948) UNGA Res 217 A(II) (UDHR), preamble, art 1, 2, 7.

UNSC Res 1296 (19 April 2000) UN Doc S/RES/1296.

UNSC Res 1314 (11 August 2000) UN Doc S/RES/1314.

UNSC Res 1325 (31 October 2000) UN Doc S/RES/1325.

Valentini, Laura. 2012. Ideal vs. Non-ideal Theory: A Conceptual Map. Philosophical Compass 7 (9): 654-664.

Women's International League for Peace and Women. 2015. Localising the Women Peace and Security Agenda: A Toolkit for Leveraging UNSCR 1325's 15th Anniversary. https://wilpf.org/wp-content/ uploads/2015/09/PeaceWomen_October-2015-High-Level-Review_WILPF-Sections-AdvocacyToolkit.pdf. Accessed 9 Oct 2019.

Publisher's Note Springer Nature remains neutral with regard to jurisdictional claims in published maps and institutional affiliations. 